\title{
Transmission of exchange rate variation to Brazilian pulp export prices
}

\author{
Leonardo Sangoi Copetti ${ }^{*}$ iD Daniel Arruda Coronel $^{2}$ iD
}

\begin{abstract}
'Pós-graduação em Estatística e Modelagem Quantitativa.Universidade Federal de Santa Maria (UFSM), 97105-900, Santa Maria, RS, Brasil. E-mail: leonardocopetti@hotmail.com. "Corresponding author.

${ }^{2}$ Departamento de Economia e Relações Internacionais, Universidade Federal de Santa Maria (UFSM), Santa Maria, RS, Brasil.
\end{abstract}

\begin{abstract}
The aim of this research was to examine the relationship between exchange rate variations and Brazilian export prices for cellulose, which is defined as the exchange rate pass-through, taking the period from January 2000 to March 2019 as a reference. The data were collected on the websites of the Ministry of Development, Industry and Foreign Trade - MDIC, the Institute of Applied Economics - IPEA and the Federal Reserve Bank of St. Louis - FRED. Thus, time series instruments were used, especially the Error Correction Vector Model. Results provided indications that the pass-through degree of exchange rate for cellulose export prices occurred incompletely in the total period and in the second sub-period, and was null in the first sub-period, representing that depreciation of rate exchange rates did not translate into significant competitiveness gains, as they did not significantly reduced export prices.
\end{abstract}

Key words: cellulose, export prices, pass-through.

Transmissão da variação da taxa de câmbio para os preços brasileiros de exportação da celulose

RESUMO: O objetivo deste trabalho consistiu no exame da relação entre as variaçães cambiais e os preços de exportação brasileiros da celulose, relação definida como o pass-throughda taxa de câmbio, tendo como referência o período de janeiro de 2000 a março de 2019. Os dados foram coletados nos sites do Ministério do Desenvolvimento, Indústria e Comércio Exterior - MDIC, no Instituto de Economia Aplicada -IPEA e no Federal Reserve Bank of St. Louis - FRED. Neste sentido, fez-se uso dos instrumentais de séries temporais, especialmente do Modelo Vetor de Correção de Erros. Os resultados encontrados forneceram indicações de que o grau de pass-throughda taxa de câmbio para os preços de exportação da celulose ocorreram de forma incompleta no periodo total e no segundo sub-período, e nula no primeiro sub-período, representando que depreciações da taxa de câmbio não se traduzem em ganhos significativos de competitividade, dado que não reduzem expressivamente os preços de exportação.

Palavras-chave: celulose, preços de exportação, pass-through.

\section{INTRODUCTION}

According to the International Trade Center - ITC (2019), Brazil is the world's largest exporter of cellulose, since in 2018 , the total exported was 15.31 million tons, which represented $23.64 \%$ of exports worldwide, that was of 64.75 million tons. Besides that, according to the Ministry of Development, Industry and Foreign Trade (MDIC, 2019), the total cellulose exported by Brazil in 2018 was of US \$ 8.35 billion, representing $3.48 \%$ of total exports. Comparing with 2000, there was an increase of $422 \%$ in the exports of this commodity, since exports amounted US $\$ 1.60$ billion

ITC data (2019), describes the three largest world exporters of cellulose in 2018 were; respectively, Brazil, with 15.31 million tons (23.64\%); Canada, with 9.75 million tons $(15.05 \%)$ and the United States, with 7.83 million tons $(12.09 \%)$. Conversely, the three largest world pulp importers were; respectively, China, with 24.43 million tons $(36.85 \%)$; United States, with 5.56 million tons $(8.39 \%)$ and Germany, with 4.74 million tons $(7.15 \%)$. Furthermore, according to the World Trade Organization - WTO (2019), these three largest importers did not apply import duties to the commodity.

OBSTFELD et al. (1995), considered that macroeconomic policies optimal for a region depend, among other factors, on how exporters define their prices, whether they fix their prices based on their own currency (producer currency pricing - PCP), 
or based on the destination market currency (local currency pricing - LCP), and this choice influences the macroeconomic environment through the foreign exchange pass-through degree (pass-through) to prices. So, in the case of PCP, an exchange rate depreciation produces a reduction in the price in the currency destination exports, increasing the quantity demanded, and in the case of LCP, an exchange rate depreciation produced an increase in the exporter's mark-up, without changing the amount of the demand.

In addition, another point of relevance in determining the degree of foreign exchange passthrough is the perception of exporters on whether changes in the exchange rate are transient or permanent. For TEJADA et al. (2008), the change in the exchange rate perceived as transitory will have little effect on the determination of export prices; conversely, the greater reliability in forecasting the future exchange rate was related to a greater effect on prices exports and the entirely pass-through of the foreign exchange to prices.

In the economic literature, several studies showed a partial influence of exchange rate variations on the country's export prices, representing the incomplete pass-through as the researches carried out by FERREIRA et al. (1999) CRUZ JR. et al. (2004), TEJADA et al. (2008), FRAGA et al. (2008), CORREA (2012), COPETTI et al. (2012, 2013), SOUZA et al. (2018).

In this context, the research problem of this study was to answer the following question: there is a difference between the pass-through degree for Brazilian cellulose export prices in the total period from $01 / 2000$ to $03 / 2019$, and in the sub -periods from $01 / 2000$ to $02 / 2008$ and $03 / 2008$ to $03 / 2019$ ? In addition, the objective of the study was to examine the relationship between exchange rate variations and Brazilian export prices for cellulose, using the period from January 2000 to March 2019 as a reference.

To the development of this study, there are elements to understand the magnitude with which the transmission of prices to the cellulose market takes place, as well as to understand more about how the economic and exchange rate policy can impact on the competitiveness of Brazilian exporter.

COSTA et al. (2015) analyzed the competitiveness of the main products in the paper and cellulose segment exported by Brazilian companies, in the period from 1995 to 2010. Therefore, the authors used the competitiveness matrix, classifying the exported products in backward sectors, characterized by products with a negative growth rate on the world market and in the Symmetrical Revealed
Comparative Advantage (VCRS) index which is declining. Declining sectors are characterized by products with a negative growth rate on the world market and positive VCRS. Post opportunities had products showing positive growth rate and negative VCRS; and excellent sector had products with positive VCRS and growth rate. As a result, the two products analyzed in the cellulose segment (pulp, soda or sulfate, except for dissolving pastes, of nonconiferous; and dissolving pulp), in the analysis in sub-periods, presented positive performance, migrating from the "sector in decline "for the" optimal sector", and in the full period analysis, both were positioned in the" optimal sector".

OLAVO et al. (2015) carried out a research on the competitiveness of Brazilian paper and cellulose exports and on the 12 largest world producing countries, in the period from 1990 to 2013. For this purpose, the authors used Bowen's indexes, the Revealed Comparative Advantage (VCR) index, the Symmetric Comparative Advantage Index (VCRS), the Trade Balance Contribution Index (ICSC), the HerfindahlHirschman index and the Constant Market Share model (CMS). As a result of the VCR, VCRS and the CMS model, they reported high pulp competitiveness. Notwithstanding this, it is clear that there are still few studies involving the competitiveness of Brazilian cellulose and the pass-through coefficient, to which this research comes to contribute.

The present research is structured in three sections, in addition to this introduction. In the second section, the empirical studies carried out on price transmission and the pass-through coefficient in the Brazilian market are presented; in the third section, methodological procedures are outlined; in the next section, the results are analyzed and discussed; and finally, in the last section, the main conclusions of the research are presented.

\section{Transmission of prices and coefficient of pass- through in the brazilian market}

FERREIRA et al. (1999) investigated the relationship between the exchange rate and the prices of Brazilian manufactured exports, with quarterly data, from March 1978 to April 1996, divided into two sub-periods, from March 1978 to April from 1985 and from January 1986 to April 1996. For this purpose, time series econometrics based on the methodology of Engle \& Granger, Shin and Johansen were used. As a result, in the period from March 1978 to April 1996, the authors reported that there 
was an incomplete pass-through coefficient and that exchange rate variations partially influenced export prices. In the sub-period from January 1986 to April 1996, the pass-though was close to zero, indicating that changes in the exchange rate may not have had any influence on the prices of Brazilian manufactured exports, with changes in prices export basically explained by the movement in international prices. The authors suggested that this result is linked to the option of Brazilian exporters for not changing their prices in foreign currency, due to the extreme exchange rate instability that characterized this period. Thus, in order to preserve their participation in foreign markets, exporters have chosen to keep their prices in foreign currency invariable to changes in the exchange rate that are perceived as transitory.

CRUZ JR. et al. (2004) studied the passthrough coefficient for the quarterly export of Brazilian agricultural products in the period from the 3rd quarter of 1994 to the 2nd quarter of 2003. The following series were used to estimate the model: export price index for agricultural products in Brazil, the wholesale price index for export crops (IPA-OG) as a proxy for the production cost, the nominal exchange rate (real / dollar) at the end of the period, and, for the international price, a series of import prices for commodities from the United States. The authors used time series econometrics and the Vector Error Correction model - VEC. As a result, the authors estimated a pass-through coefficient of -0.53 , representing that changes in the exchange rate partially affected the export price of Brazilian agricultural products.

TEJADA et al. (2008) analyzed the relationship between exchange rate variations and the prices of exports of the main products exported by Brazil, with quarterly data, from January 1980 to January 2004. The sectors surveyed and the respective participation in the year 2004 were Car Parts and Other Vehicles (10.29\%), Steel (7.11\%), Mineral Extraction (8.41\%), Machinery and Tractors - MAQ (5.33\%), Motor Vehicles (5.05\%), Vegetable Oils (4.96\%), Oil Refining (4.55\%), Wood and Furniture $(4.14 \%)$, Processing of Vegetable Products (3.22\%), Non-ferrous Metallurgy (3.16\%) $\%)$, Pulp, Paper and Graphics (3.06\%), Electrical Material (2.34\%), Chemical Elements (2.15\%), and Electronic Equipment (2.10\%). To estimate the passthrough coefficient, the authors used the Kalman filter, generating a variable coefficient over time. As a result, the sectors analyzed showed a coefficient of pass-through oscillating between zero and -1 (minus one), and a pass-through for cellulose, paper and printing sector with value oscillating between the averages of -0.2233 to -0.2981 , indicating incomplete pass-through, that is, the exchange rate variation partially affects export prices.

FRAGA et al. (2008) investigated the transfer of the exchange rate variation to the monthly export prices of soybeans from Brazil in the period from July 1994 to December 2004. Therefore, the authors used unit root tests (ADF), from Johansen co-integration and the vector error correction model (VEC). Results indicated a pass-through coefficient of -0.34 , representing an incomplete pass-through, that is, that exchange rate variations did not translate into significant competitiveness gains, affecting only the mark-up of the exporter.

CORREA (2012) analyzed the impact of exchange rate variations on exports from 26 sectors of the Brazilian economy, from 1995 to 2005. The variables used in the econometric model were the price of Brazilian exports from 26 sectors classified by the Brazilian Institute of Geography and Statistics - IBGE, the nominal exchange rate, the domestic cost using a sectorial cost methodology, the price of international competing exports corresponding to the price index of North American imports and the degree of utilization of installed capacity calculated by Fundação Getúlio Vargas - FGV . As a result, the research indicated incomplete pass-through coefficients for the various sectors researched and a pass-through of -0.701 for the paper and printing sector.

COPETTI, et al.,2012) carried out a research on the transmission of the exchange rate variation to soybean export prices in Brazil and Argentina, from 03/1999 to 02/2011. Therefore, they used econometrics of time series and the Vector Error Correction model VEC. Results revealed an incomplete pass-through coefficient for Brazil (-0.11) and null for Argentina. In the Brazilian market, the coefficient estimate indicated that the variation in the exchange rate had a partial influence on the average export prices of soybeans, that is, the variation of $1 \%$ in the exchange rate is passed on by $0.11 \%$ in the same direction for the average export price of soybeans in Brazil. As for the Argentine market, exchange rate variations had no influence on average soybean export prices

Another study developed by COPETTI et al. (2013) analyzed the relationship between the exchange rate (real / euro - $\mathrm{R} \$ / €$ ) and the export prices of soybeans between the United States, Brazil and Argentina (in euro / tonnes - $€ /$ tonnes), from January 2003 to January 2012. For this purpose, the authors used stationarity series tests (ADF and KPSS), the Johansen co-integration test and the Vector Error Correction model - VEC. As a result, an incomplete 
pass-through coefficient for the United States and null coefficients for Brazil and Argentina were identified. In the North American market, the coefficient of -0.65 indicated partial influence of the exchange rate variation (dollar / euro - US \$ / €) on the export price of soybean ( $€ /$ tons), and a variation of $0.65 \%$ in the same direction as the export price of soybean produced by the $1 \%$ variation in the exchange rate. In the Brazilian and Argentine markets, the exchange rate variation did not influence the export prices of soybeans.

SOUZA et al. (2018) evaluated the exchange rate pass-through for Brazilian sugar export prices, in dollars and reais, from January 2012 to December 2016. The authors used the time series econometric tools multivariate methods, with emphasis on the Vector Error Correction Model. Results demonstrated an incomplete pass-through of the exchange rate for sugar export prices, in dollars and reais, with a low coefficient $(-0.03)$ of exchange pass-through for the price in dollars and a high coefficient $(0,97)$ for the price in reais.

Table 1 summarizes the studies about price transmission and the pass-through coefficient in Brazilian exports. In this subsection, studies were

Table 1 - Summary of empirical studies.

\begin{tabular}{|c|c|c|c|c|c|}
\hline Authors & $\begin{array}{l}\text { Country- } \\
\text { Contries }\end{array}$ & Períod & Products & $\begin{array}{c}\text { Methodology/ objective } \\
\text { the study }\end{array}$ & Results \\
\hline $\begin{array}{l}\text { FERREIRA et al. } \\
\text { (1999) }\end{array}$ & Brazil & $\begin{array}{l}03 / 1978- \\
04 / 1996\end{array}$ & $\begin{array}{l}\text { Manufactured } \\
\text { products }\end{array}$ & $\begin{array}{l}\text { Engle \& Granger, Shin e } \\
\text { Johansen methodology/ } \\
\text { pass-through coefficient }\end{array}$ & $\begin{array}{c}\text { incomplete } \\
\text { pass-through }\end{array}$ \\
\hline $\begin{array}{l}\text { CRUZ JR. et al. } \\
(2004)\end{array}$ & Brazil & $\begin{array}{l}3^{\circ} \text { trim./ } 1994- \\
2^{\circ} \text { trim. } / 2003\end{array}$ & $\begin{array}{l}\text { Agricultural } \\
\text { products }\end{array}$ & $\begin{array}{l}\text { Modelo Vetorial de } \\
\text { Correção de Erros/ } \\
\text { coeficiente de pass- } \\
\text { through }\end{array}$ & $\begin{array}{c}\text { incomplete } \\
\text { pass-through }(-0,53)\end{array}$ \\
\hline $\begin{array}{l}\text { TEJADA et al. } \\
(2008)\end{array}$ & Brazil & $\begin{array}{l}01 / 1980- \\
01 / 2004\end{array}$ & $\begin{array}{l}\text { sector exports / } \\
\text { cellulose, paper } \\
\text { and graphics }\end{array}$ & $\begin{array}{c}\text { Kalman filter/ pass- } \\
\text { throughcoefficient }\end{array}$ & $\begin{array}{l}\text { Incomplete pass-through } \\
\text { for various sectors qnd to } \\
\text { celulose, paper qnd } \\
\text { graphic between }-0,2233 \\
\text { a }-0,2981 \text {. }\end{array}$ \\
\hline $\begin{array}{l}\text { FRAGA et al. } \\
(2008)\end{array}$ & Brazil & $\begin{array}{c}07 / 1994- \\
12 / 2004\end{array}$ & Soybean & $\begin{array}{l}\text { Vector correction of } \\
\text { errors model pass- } \\
\text { throughcoefficient }\end{array}$ & $\begin{array}{c}\text { Incomplete pass-through } \\
(-0,34)\end{array}$ \\
\hline CORREA (2012) & Brazil & $1995-2005$ & sector exports & $\begin{array}{l}\text { Time series econometry / } \\
\text { pass-through coefficient }\end{array}$ & $\begin{array}{l}\text { incomplete pass-through } \\
\text { for the researched sectors } \\
\text { and for the paper and } \\
\text { graphic sector in the } \\
\text { amount of }-0.701\end{array}$ \\
\hline $\begin{array}{l}\text { COPETTI et al. } \\
(2012)\end{array}$ & $\begin{array}{l}\text { Brazil e } \\
\text { Argentina }\end{array}$ & $\begin{array}{l}03 / 1999- \\
02 / 2011\end{array}$ & Soybean & $\begin{array}{l}\text { Vector correction of } \\
\text { errors pass- } \\
\text { throughcoefficient }\end{array}$ & $\begin{array}{l}\text { Incompletepass-through } \\
\qquad(-0,11)\end{array}$ \\
\hline $\begin{array}{l}\text { COPETTI et al. } \\
(2013)\end{array}$ & $\begin{array}{l}\text { United } \\
\text { States of } \\
\text { America, } \\
\text { Brazil and } \\
\text { Argentina }\end{array}$ & $\begin{array}{l}01 / 2003- \\
01 / 2012\end{array}$ & Soybean & $\begin{array}{l}\text { Vector correction of } \\
\text { errors model pass- } \\
\text { throughcoefficient }\end{array}$ & Nullpass-through \\
\hline $\begin{array}{l}\text { SOUZA et al. } \\
(2018)\end{array}$ & Brazil & $\begin{array}{l}01 / 2012- \\
12 / 2016\end{array}$ & Sugar & $\begin{array}{l}\text { Vector Model of Error } \\
\text { Correction / pass- } \\
\text { through coefficient }\end{array}$ & $\begin{array}{c}\text { low coefficient } \\
(-0.03) \text { exchange rate } \\
\text { pass-through for prices } \\
\text { in dollars and high } \\
\text { coefficient }(0.97) \text { for } \\
\text { price in reais }\end{array}$ \\
\hline
\end{tabular}


carried out on price transmission and the pass-through coefficient in Brazilian exports in order to analyze the relationship between the exchange rate and Brazilian export prices.

The aforementioned studies revealed that Brazil had an incomplete and zero pass-through coefficient in exports. The present research innovated regarding to the studies cited by comparing the passthrough coefficient in cellulose exports in the analysis in sub-periods.

\section{MATERIALS AND METHODS}

\section{Analytical model}

The theoretical / analytical pass-through model, according to Menon (1995), used in its simplest form, is part of a mark-up model that can be represented as follows:

$$
\mathrm{P}^{*} \mathrm{X}=(1+\lambda)(\mathrm{CP} / \mathrm{E})
$$

Where $P^{*} X$ is the export price in foreign currency; $(C P / E)$ is production cost, measured in foreign currency; $E$ is the nominal exchange rate; and $\lambda$ is mark-up.

Based on the assumption that the mark-up can vary according to the competitive pressure in the world market, we have:

$$
(1+\lambda)=\left[\frac{P W}{(C P / E)}\right]^{\alpha}
$$

With: $[P W /(C P / E)]$ corresponding to the difference between the price of world exports and the exporter's production cost measured in foreign currency.

Substituting Equation (2) in (1) and applying the Neperian logarithm to the result of this substitution, we arrived at the following export price equation in foreign currency:

$$
\ln P^{*} X=(1-\alpha) \ln (C P / E)+\alpha \ln P W
$$

Considering the unrestricted version of Equation (3), in which the sum of the coefficients relative to $\ln (C P / E)$ and $\ln (P W)$ required to be equal to 1 in which the coefficients relative to $\ln (C P)$ and $\ln (E)$ differed in sign and magnitude, according to Menon (1995), we have:

$$
\ln P^{*} X=\phi_{0}+\phi_{1} \ln C P+\phi_{2} \operatorname{lxnE}+\phi_{3} \ln P W
$$

where the pass-through coefficient is represented by $\phi_{2}$.

The analysis of the result of this coefficient can be expressed as follows:
$1 . \phi_{2}=0$; it means that the exchange rate has no influence on the foreign currency price of the exported goods;

2. $\phi_{2}=-1$ or 1 ; it means that the change in the exchange rate fully affects the price in foreign currency of the exported goods; and

3. $-1<\phi_{2}<0$ or $0<\phi_{2}<1$; it means that the change in the exchange rate partially affects the price in foreign currency of the exported goods.

\section{Econometric procedures \\ Unit root test}

To determine the order of integration of the series of interest, this research used the Dickey $\&$ Fuller Augmented unit root tests (DICKEY et al., 1979, 1981) and Kwiatkowski, Phillips, Schmidt and Shin (KWIAKOWSKI et al., 1992). These tests verified the existence or not of unit roots in the time series, that is, whether the variables are stationary or not.

The ADF test consisted of estimating the following equation by Ordinary Least Squares and can be expressed, according to Enders (1995), as follows:

$$
\Delta y_{t}=\alpha_{0}+\gamma y_{t-1}+\sum_{i=2}^{p} \beta_{i} \Delta y_{t-1+1}+\varepsilon_{t}
$$

With:

$$
\begin{aligned}
& \gamma=-\left(1-\sum_{i=1}^{p} \alpha_{i}\right) \\
& \left.\beta_{i}=\sum_{j=i}^{p} \alpha_{j}\right)
\end{aligned}
$$

Where $\alpha_{0}$ is the intercept; $\gamma$ describes the behavior of the time series; $y$ represents the dependent variable; $\Delta$ is the representation of the difference operator and $\varepsilon_{t}$ denotes the error that is assumed to be independent and identically distributed. In order to determine the number of discrepancy used in the test to eliminate residual autocorrelation, the lowest value of the Schwarz criterion (SBC) was used.

The parameter of interest in the regressions (without intercept and without trend; with intercept; with intercept and trend) is $\gamma$, being that, if $\gamma=0$, the series contains a unit root. In this test, the result of 
the statistic $\tau$ is compared with the appropriate values reported by Dickey\&Fuller to determine whether to accept or reject the null hypothesis. The null hypothesis will be rejected if the calculated value of the statistic $\tau$ is greater than the critical DickeyFuller value, indicating that the series is stationary; otherwise, the series is non-stationary.

The KPSS is an alternative test to the ADF, being defined by the procedure of a non-stationary test against the null hypothesis of stationarity, according to Greene (2008). Formally it is expressed by the following expression:

$$
\begin{gathered}
y_{t}=\alpha+\beta_{t}+\gamma \sum_{i=1}^{t} z_{i}+\varepsilon_{t} \\
y_{t}=\alpha+\beta_{t}+\gamma Z+\varepsilon_{t}
\end{gathered}
$$

having the following hypotheses:

$H_{0}: \gamma=0$;, series is stationary

$H_{a}: \gamma \neq 0:$, series is not stationary

\section{Co-integration analysis}

Even if individual variables are not stationary, but there is at least one linear stationary combination between them, then it can be said that these variables are co-integrated (GREENE, 2008), that is, it is possible to verify a long-term equilibrium relationship between them, which can be estimated and analyzed. Thus, to identify the possible long-term relationship between the series, the co-integration test developed by JOHANSEN (1988) was used.

JOHANSEN's (1988) procedure considered that all variables are endogenous and their use is not limited by the existence of regressor endogeneity (causal relationship in the sense of the dependent variable to the explanatory variable). This procedure used Maximum Likelihood to estimate co-integration vectors and allows testing and estimating the presence of several vectors and not just a single co-integration vector.

According to HARRIS (1995), having defined a vector $Z_{t}$ of $n$ potentially endogenous variables, it is possible to specify the following generating process, and model $Z_{t}$ as an unrestricted Auto-regressive Vector (VAR) with k lags of $Z_{t}$ :

$$
z_{t}=A_{1} z_{t-1}+\ldots+A_{k} z_{t-k}+u_{t}
$$

where: $Z_{t}$ is a vector $(n x 1)$, is a matrix of parameters $n x n)$ e $u_{t} \sim I D\left(\mu, \sigma^{2}\right)$.

Also according to Harris (1995), Equation (7) can be reparametrized in terms of a Vector Error Correction (VEC) model outlined as:

$$
\Delta z_{t}=\Gamma_{1} z_{t-1}+\ldots+\Gamma_{k-1} \Delta z_{t-k+1}+\Pi z_{t-k}+\varepsilon_{t}
$$

em que $\Gamma_{\mathrm{i}}=-\left(\mathrm{I}-\mathrm{A}_{1}-\ldots-\mathrm{A}_{i}\right) \quad(\mathrm{i}=1, \ldots, \mathrm{k}-1)$ $\Pi=-\left(\mathrm{I}-\mathrm{A}_{1}-\ldots-\mathrm{A}_{k}\right)$.

As specified, the system contains short and long-term information on changes in $Z$, via estimates of $\hat{\boldsymbol{\Gamma}}_{\boldsymbol{i}}$ and $\hat{\boldsymbol{I}}$, respectively, where, $\boldsymbol{D}=\boldsymbol{a} \hat{\boldsymbol{a}}^{\prime}$ with $\alpha$ representing the speed of adjustment to the imbalance and $\beta$ the long-term coefficient matrix.

The importance of the error correction model lies in the fact that it allows the connection between aspects related to short-term and long-term dynamics (HAMILTON, 1994). Thus, the error correction mechanisms aim to provide a way to combine the advantages of modeling both in level and in differences. In this model, not only the dynamics of the short-term adjustment process but also the longterm process are modeled simultaneously.

The number of co-integration vectors depends on the rank or rank (r) of the matrix $\Pi$ . In terms of co-integration vectors, there are three possibilities, according to Enders (1995): if the rank of is complete, then the variables $Y_{t}$ are I (0), that is, it means that any linear combination between the variables is stationary and the adjustment of the model must be carried out with the variables level; if the rank $\Pi$ is zero, then there is no co-integration relationship and the model must be adjusted with the variables in difference and, when there is a reduced rank $\Pi$, there are cointegration vectors.

For Enders (1995), the rank of a matrix is equal to the number of characteristic roots strictly different from zero, which can be identified by means of two statistical tests. The first is the trace test, which tests the null hypothesis that the number of distinct co-integration vectors is less than or equal to $r$ against the alternative hypothesis that the number of these vectors is greater than $r$, which can be defined by:

$$
\lambda_{\text {trace }}(r)=-T \sum_{i=r+1}^{n} \ln \left(1-\lambda_{i}^{\prime}\right)
$$

Where $\lambda_{i}^{\prime}=$ estimated values of the characteristic roots obtained from the matrix; $T=$ number of observations.

The second test is the maximum eigen value test, which tests the null hypothesis that the number of co-integration vectors is $\mathrm{r}$ against the alternative hypothesis of $r+1$ co-integration vectors, which can be expressed as follows: 


$$
\lambda_{\max }(r, r+1)=-T \ln \left(1-\lambda_{r+1}^{\prime}\right)
$$

Once the co-integration between the analyzed series was verified, the VEC model is estimated, as defined in Expression (8).

\section{Self-correlation tests \\ Portmanteau test}

The Portmanteau test calculates multivariate Box-Pierce / Ljung-Box statistics for residual serial correlation up to the specified lag.

BOX \& PIERCE (1970) developed a $Q$ statistic based on the sum of the squares of the autocorrelations. The Box-Pierce statisticis $Q=T * \sum_{k=1}^{q} \rho_{k}^{2}$ compared to the chi-square distribution with " $q$ " degrees of freedom. If the residue is a white noise, the defined $Q$ statistic follows a chisquare distribution with "q" degrees of freedom.

LJUNG-BOX (1978), also known as the modified Box-Pierce test, is used to verify if there is an adjustment failure in a temporal model. The test examined the first " $n$ " autocorrelations of the residues and, if they are small, there is an indication that there is no failure in the adjustment. The null hypothesis of this test considered that the autocorrelations up to lag " $n$ " are equal to zero and the test statistic is defined by Equation (11):

$$
Q^{*}=T *(T-2) \sum_{k}^{n} \frac{\hat{\rho}_{k}^{2}}{T-k}
$$

where $\rho k$ the estimated autocorrelation of the residues in the lag " $\mathrm{k}$ " and " $\mathrm{n}$ " the number of

$Q^{*}>x_{1-\alpha ; q}^{2} x_{1-\alpha ; q}^{2}$ lags tested. The test will reject the null case hypothesis, being a chi-square distribution with " $q$ " degrees of freedom and level of significance $\alpha$.

\section{LM test}

The BREUSCH (1978) - GODFREY (1978) test, also known as the LM (Lagrange Multiplier) test for autocorrelation, tests the null hypothesis of absence of autocorrelation until the $p$ lag. After defining the model and estimating its coefficients, the test consisted of performing a regression of the residue against the time-lagged residue itself and the explanatory variables, according to Equation (12).

$\hat{u}_{t}=\alpha_{0}+\alpha_{1} x_{t}+\hat{\rho}_{1} \hat{u}_{t-1}+\hat{\rho}_{2} \hat{u}_{t-2}+\ldots+\hat{\rho}_{p} \hat{u}_{t-p}+v_{t}$ where $\hat{u}_{t-1}, \hat{u}_{t-2}, \ldots, \hat{u}_{t-p}$ the last terms are the residuals estimated by the model equation adopted.

The data for estimating the model presented in Equation (4) were collected at the following sites: at the Ministry of Development, Industry and Foreign Trade - MDIC (2019), for the variable cellulose export price (dividing the total value in dollars by the quantity in kilograms and transforming in dollars per ton - US \$ / ton), at the Institute of Applied Economics - IPEA (2019), for the production cost variables, using as a proxy the Wholesale Price Index - Internal Availability - IPA-DI, and nominal exchange rate (in reais / dollars - R \$ / US \$); and the Federal Reserve Bank of St. Louis - FRED (2019) for the international pulp price variable, using as a proxy the import price index for pulp, recovered paper and paper products from the United States. The period analyzed was from January 2000 to March 2019, with monthly quotations, totaling 231 observations. The series were also separated into 2 (two) sub-periods: January 1, 2000 to February 2008; and 02 - from March 2008 to March 2019.

Table 2 presents a summary of the variables estimated in the model.

In the next section, the analysis and discussion of the results of cellulose models estimated in the total period and sub-periods will be presented.

\section{RESULTS AND DISCUSSION}

To indicate the order of integration of the analysis series, two stationarity tests were applied:

Table 2 - Variables estimated in the model and the respective Initials.

\begin{tabular}{lc}
\hline Variable & Initials \\
\hline Log pulp export price / total period & LBRA_C \\
Log pulp export price / sub-period 01 & LBRA_C01 \\
Log pulp export price / sub-period 02 & LBRA_C02 \\
Log production cost in Brazil / total period & LBRA_CP \\
Log production cost in Brazil / sub-period 01 & LBRA_CP01 \\
Log production cost in Brazil / sub-period 02 & LBRA_CP02 \\
Log exchange rate Real / Dollar / total period & LTX_D \\
Real /Dollar/Sub-period exchange rate log 01 & LTX_D01 \\
Real /Dollar/Sub-period exchange rate log 02 & LTX_D02 \\
International pulp price log / total period & LINT_C \\
International pulp price log / sub-period 01 & LINT_C01 \\
International pulp price log / sub-period 02 & LINT_C02 \\
\hline
\end{tabular}

Ciência Rural, v.50, n.8, 2020. 
ADF - Dickey\&Fuller Augmented; and KPSS Kwiatkoswski, Philips, Schmidt and Shin. The results are shown in tables 3 and 4.

By analyzing table 3 , it is observed that the variables export price in sub-period 01 (LBRA C01), export price in sub-period 02 (LBRA_C02), exchange rate in sub-period 01 (LTX_D01) and international price in sub-period 02 (LINT_C02) were stationary in level for the KPSS test, with 5\% of significance, being the other series non-stationary in level, for the ADF and KPSS tests, that is, their average, variances or both vary over time. Conversely, the results in table 4 indicated agreement in both tests, with the first difference performed, the series were stationary, with a $5 \%$ significance level.

After the stationarity tests of the series were carried out and the order of integration was identified - all variables were integrated in order 1 (I (1)), and the next step was to individually analyze the dynamics of the exchange rate pass-through in cellulose export prices in the total period $t$ and in the two sub-periods.

Cellulose - total period - from Jan / 2000 to Mar / 2019 In figure 1 , it is possible to identify the evolution of the export price of cellulose (in US \$ / tons) and the nominal exchange rate (R \$ / US \$) from January 2000 to March 2019.
From figure 1, it was identified that the series showed a stochastic trend, that is, a random pattern over time. However, it is possible that the data showed a long-term relationship to be confirmed by the co-integration test.

To perform the co-integration test, it is necessary to check the number of lags to insert in the model (Table 5).Based on the data in table 5, it was possible to indicate that the number of lags is 4 (four) to be included in the VAR, since, of the five criteria considered, three indicated the same number of lags in the auxiliary VAR.

The Johansen co-integration test revealed that in the null hypothesis there was no co-integration vector, as well as in the alternative hypothesis there was at least one co-integration vector to be rejected at the level of $1 \%$ for the trait statistic and for the maximum eigen value statistic (according to the data in table 6). In addition, the model of the co-integration equation that best fitted the test was case 1 of the test summary, for the Schwarz and Akaike criteria, with the variables at a level without deterministic tendency and the co-integration equations without intercepts.

According to table 7, which presents the co-integration vector (normalized), all the estimated coefficients were significant at the level of $5 \%$. In

Table 3 - Level root unit tests applied in the monthly series of pulp export prices (in US \$ / ton), production cost, nominal exchange rate (R \$ / US \$) and international pulp prices (index of U.S. import prices for pulp, recovered paper and paper products) from January 2000 to March 2019.

\begin{tabular}{|c|c|c|c|c|c|c|}
\hline \multirow{3}{*}{$\begin{array}{l}\text { Series } \\
\text { LBRA_C }\end{array}$} & \multicolumn{3}{|c|}{ 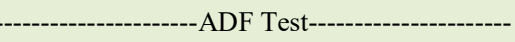 } & \multicolumn{3}{|c|}{ 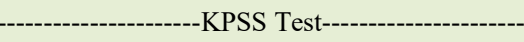 } \\
\hline & Model & \multicolumn{2}{|c|}{ Statistic test } & Model & \multicolumn{2}{|c|}{ Statistic test } \\
\hline & constant & -2.205402 & ns & constant & 0.722200 & ** \\
\hline LBRA_C01 & constant & -1.694153 & ns & constant & 0.216959 & ns \\
\hline LBRA_C02 & constant & -2.537244 & ns & constant & 0.114743 & $\mathrm{~ns}$ \\
\hline LBRA_CP & constant & -2.141412 & ns & constant & 1.925908 & **** \\
\hline LBRA_CP01 & constant & -1.592245 & ns & constant & 1.234673 & *** \\
\hline LBRA_CP02 & constant & -0.404322 & ns & constant & 1.415637 & *** \\
\hline LTX_D & constant & -1.365241 & ns & constant & 0.495230 & ** \\
\hline LTX_D01 & constant & -1.225740 & ns & constant & 0.326678 & $\mathrm{~ns}$ \\
\hline LTX_D02 & constant & -0.905341 & ns & constant & 1.242786 & *** \\
\hline LINT_C & constant & -1.361081 & ns & constant & 1.470545 & *** \\
\hline LINT_C01 & constant & -0.200220 & ns & constant & 0.776710 & *** \\
\hline LINT_C02 & constant & -2.633638 & * & constant & 0.144405 & $\mathrm{~ns}$ \\
\hline
\end{tabular}

Note $1:{ }^{* * *}$ significant at $1 \% ;{ }^{* *}$ significant at $5 \% ;{ }^{*}$ significant at $10 \%$; ns not significant 
Table 4 - Unit root tests in first difference applied in the monthly series of cellulose export prices (in US \$ / ton), production cost, nominal exchange rate (R \$ / US \$) and international cellulose prices (index of US import prices for cellulose, recovered paper and paper products) from January 2000 to March 2019.

\begin{tabular}{|c|c|c|c|c|c|c|}
\hline \multirow{2}{*}{$\begin{array}{l}\text { Series } \\
\text { LBRA_C }\end{array}$} & \multirow{2}{*}{$\begin{array}{c}\text { Model } \\
\text { constant }\end{array}$} & \multicolumn{2}{|c|}{-----------Statistic Test----------- } & \multirow{2}{*}{$\begin{array}{c}\text { Model } \\
\text { constant }\end{array}$} & \multicolumn{2}{|c|}{--------------Statistic--------------- } \\
\hline & & -13.31504 & $* * *$ & & 0.048549 & ns \\
\hline LBRA_C01 & constant & -9.512011 & $* * *$ & constant & 0.197481 & ns \\
\hline LBRA_C02 & constant & -8.432568 & $* * *$ & constant & 0.043645 & ns \\
\hline LBRA_CP & constant & -6.635375 & $* * *$ & constant & 0.324612 & ns \\
\hline LBRA_CP01 & constant & -3.461514 & $* *$ & constant & 0.225223 & $\mathrm{~ns}$ \\
\hline LBRA_CP02 & constant & -6.572213 & $* * *$ & constant & 0.035224 & ns \\
\hline LTX_D & constant & -10.09791 & $* * *$ & constante & 0.127696 & $\mathrm{~ns}$ \\
\hline LTX_D01 & constant & -6.734336 & $* * *$ & constant & 0.461530 & $*$ \\
\hline LTX_D02 & constant & -7.489350 & $* * *$ & constant & 0.070966 & ns \\
\hline LINT_C & constant & -5.330087 & $* * *$ & constant & 0.050841 & ns \\
\hline LINT_C01 & constant & -6.448478 & $* * *$ & constant & 0.200860 & ns \\
\hline LINT_C02 & constant & -6.926518 & $* * *$ & constant & 0.152205 & ns \\
\hline
\end{tabular}

Note $1:{ }^{* * *}$ significant at $1 \% ;{ }^{* *}$ significant at $5 \% ;{ }^{*}$ significant at $10 \%$; ns not significant.

equation (13), the co-integration vector (normalized) is shown, indicating the long-term relationship between the variables and the respective elasticities.

$L B R A_{-} C_{t}=+0,17 L B R A_{-} C P_{t}-0,32 L T X_{-} D_{t}+1,12 L I N T_{-} C_{t}$
According to Equation (13), it was verified that the pass-through coefficient was incomplete, indicating that the exchange rate variation $(\mathrm{R} \$$ / US \$) partially influenced the export price of Brazilian cellulose, that is, the variation of $+1 \%$ in the exchange rate causes a change of $-0.32 \%$ in the

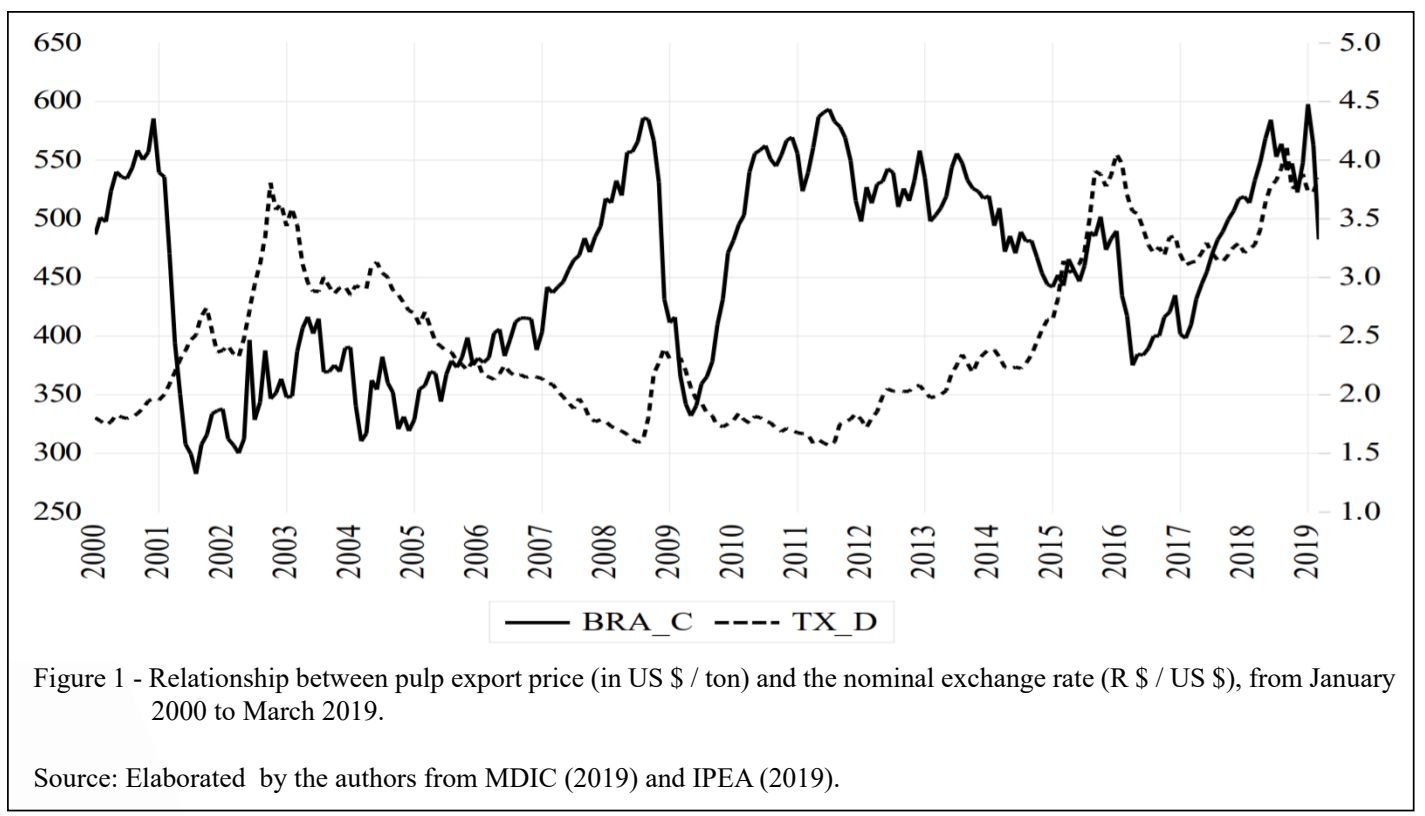

Ciência Rural, v.50, n.8, 2020. 
Table 5 - VAR criteria discrepancy for cellulose - total period.

\begin{tabular}{|c|c|c|c|c|c|c|}
\hline Discrepancy & $\log L$ & LR & FPE & AIC & $\mathrm{BIC}$ & HQ \\
\hline 1 & 2352.426 & NA & $1.93 \mathrm{e}-14$ & -20.22879 & -19.99036 & -20.13263 \\
\hline 2 & 2459.722 & 207.1612 & $8.74 \mathrm{e}-15$ & -21.01924 & $-20.54237^{*}$ & $-20.82690^{*}$ \\
\hline 3 & 2474.944 & 28.86208 & $8.80 \mathrm{e}-15$ & -21.01250 & -20.29719 & -20.72399 \\
\hline 4 & 2499.556 & $45.81538^{*}$ & $8.18 \mathrm{e}-15^{*}$ & $-21.08707^{*}$ & -20.13333 & -20.70239 \\
\hline
\end{tabular}

Note 1: likelihood value ( $\operatorname{LogL})$; p-value of the likelihood ratio test (LR); Final Prediction Error (FPE); Akaike Information Criteria (AIC); Schwarz Bayesian Information Criteria (BIC); and the Hannan\& Quinn (HQC) Information Criteria.

Note $2:{ }^{*}$ indicates the optimal lag (n) defined by the criterion.

export price of cellulose. The study by TEJADA et al. (2008) also reported an incomplete pass-through coefficient for cellulose, paper and printing sector with a value ranging from the means of -0.2233 to -0.2981 , and the study by CORREA (2012) reported a pass-through in the amount of -0.701 for the paper and printing sector; however, the analysis periods of the two studies are different from this research. Other revised studies on the transfer of exchange rate variations to Brazilian export prices, for other products and sectors, also corroborated the result of an incomplete pass-through (FERREIRA et al., 1999; CRUZ JR. et al., 2004, FRAGA et al, 2008, COPETTI et al., 2012; SOUZA et al., 2018).

In equation (13), it can be seen that the variation of $+1 \%$ in the cost of Brazilian production causes a variation of $+0.17 \%$ in the export price of cellulose. It was also possible to infer, based on Equation (13), that the variation of $+1 \%$ in the international price of cellulose determined a variation of $+1.12 \%$ in the export price of this commodity. The result reported in the present research suggested an

Table 6 - Johansecointegrationtest forcellulose - total period.

\begin{tabular}{ccccc}
\hline & \multicolumn{2}{c}{ Trace statistic } & \multicolumn{2}{c}{$\begin{array}{c}\text { Maximum statistic } \\
\text { Eigenvalue }\end{array}$} \\
\hline & Calculated & P-value & Calculated & P-value \\
$\mathrm{R}=0$ & $47.97357^{* * *}$ & 0.0068 & $29.28020^{* * *}$ & 0.0093 \\
$\mathrm{R} \leq 1$ & 18.69338 & 0.2151 & 15.73233 & 0.0995 \\
$\mathrm{R} \leq 2$ & 2.961052 & 0.8525 & 2.406756 & 0.8736 \\
\hline
\end{tabular}

Note: ${ }^{* *}$ significant at $5 \%$ and ${ }^{* * *}$ significant at $1 \%$. elastic coefficient in the transmission of prices and validates the Single Price Law, which, according to Mundlack et al. (1992), states that identical goods, in different regions, in free market competition, should be sold for the same price. For the purpose of diagnosis and robustness of the model, two serial correlation tests were estimated for the residues, results which are shown in table 8 .

Based on the analysis of the data presented in table 8 , up to twelve defaults, the test indicated the rejection of the null hypothesis, in which the serial correlation was different from zero, with $1 \%$ significance. Thus, the diagnostic results of the estimated model are valid and present a correct and reliable relationship between the variables in question.

Table 7 - Co-integration estimation vector (normalized) for cellulose - total period.

\begin{tabular}{lccc}
\hline $\begin{array}{l}\text { LBRA_C } \\
(-1)\end{array}$ & $\begin{array}{c}\text { LBRA_CP } \\
(-1)\end{array}$ & LTX_D (-1) & LINT_C (-1) \\
\hline 1,0000 & $-0.171730^{* *}$ & $0.319074^{* * *}$ & $-1.124595^{* * *}$ \\
& $(0.06772)$ & $(0.08496)$ & $(0.08303)$ \\
& {$[-2.53579]$} & {$[3.75578]$} & {$[-13.5439]$} \\
\hline
\end{tabular}

Note 1: LBRA_C $=$ Neperian logarithm of the cellulose export price - total period (US \$ / ton); LBRA_CP = Neperian logarithm of the production cost - total period; LTX_D = Neperian exchange rate logarithm - total period (R \$ / US \$); LINT_C $=$ Neperian logarithm of the international cellulose price - total period (North American import price index for cellulose, recovered paper and paper products).

Note 2: the values in parentheses refer to the standard error, and those in brackets, to the $\mathrm{t}$ statistic. Note $3:{ }^{* * *}$ significant at $1 \% ;{ }^{* *}$ significant at $5 \%$, ns not significant. 
Table 8 - Serial correlation tests for waste from the VEC model for cellulose - total period.

\begin{tabular}{|c|c|c|c|c|c|c|}
\hline Discrepancy & Est. Q & p-value & Est Ajust.Q & p-value & Est. LM & p-value \\
\hline 1 & 1.100241 & --- & 1.105025 & --- & 15.26246 & 0.5055 \\
\hline 2 & 3.793977 & --- & 3.822287 & --- & 15.92648 & 0.4581 \\
\hline 3 & 5.406831 & --- & 5.456363 & --- & 10.14786 & 0.8588 \\
\hline 4 & 11.87941 & --- & 12.04299 & --- & 23.35264 & 0.1046 \\
\hline 5 & 19.83020 & 0.8706 & 20.16968 & 0.8582 & 10.77979 & 0.8229 \\
\hline 6 & 33.23820 & 0.8818 & 33.93523 & 0.8633 & 15.43284 & 0.4932 \\
\hline 7 & 54.93589 & 0.6608 & 56.31097 & 0.6113 & 23.32700 & 0.1053 \\
\hline 8 & 74.86774 & 0.5152 & 76.95787 & 0.4477 & 21.42271 & 0.1628 \\
\hline 9 & 90.66842 & 0.5197 & 93.39912 & 0.4397 & 18.33277 & 0.3048 \\
\hline 10 & 110.0101 & 0.4281 & 113.6160 & 0.3369 & 21.37179 & 0.1647 \\
\hline 11 & 124.2521 & 0.4767 & 128.5700 & 0.3711 & 16.23798 & 0.4365 \\
\hline 12 & 137.7598 & 0.5377 & 142.8180 & 0.4180 & 14.63382 & 0.5516 \\
\hline
\end{tabular}

In the next subsections, the analyzes in sub-periods will be presented as a way to test the stability of the exchange rate relationship and the cellulose export prices.

Analysis of the sub-period 01 - from Jan / 2000 to $\mathrm{Feb} / 2008$

To perform the co-integration test, it is necessary to check the number of lags to insert the model (Table 9). Based on the data in table 9, it was possible to indicate that the number of lags is 2 (two) to be included in the VAR, since, of the five criteria considered, all indicated the same number of lags in the auxiliary VAR.
The Johansen co-integration test revealed in the null hypothesis that there is no co-integration and the vector should be rejected at the 5\% level (according to the data in table 10). In addition, the model of the co-integration equation that best fitted the test was case 1 of the test summary, for the Schwarz and Akaike criteria, with the variables at a level without deterministic tendency and the cointegration equations without intercepts.

According to table 11, which presents the co-integration vector (normalized), only the passthrough coefficient was not significant, at the level of $10 \%$, but the other estimated coefficients were significant at the level of $1 \%$.

Table 9 - Discrepancy Criteria for auxiliary VAR for cellulose - sub-period 01.

\begin{tabular}{lcccccc}
\hline Defasagem & LogL & LR & FPE & AIC & BIC \\
\hline 1 & 978.2296 & NA & $3.48 \mathrm{e}-14$ & -19.63734 & -19.21530 & -19.46663 \\
2 & 1043.027 & $119.0152^{*}$ & $1.29 \mathrm{e}-14^{*}$ & $-20.63320^{*}$ & $-19.78913^{*}$ & $-20.29179^{*}$ \\
\hline 3 & 1049.802 & 11.89068 & $1.56 \mathrm{e}-14$ & -20.44493 & -19.17883 & -19.93282 \\
\hline 4 & 1064.107 & 23.93991 & $1.63 \mathrm{e}-14$ & -20.41035 & -18.72221 & -19.72753 \\
\hline
\end{tabular}

Note 1: likelihood value $(\operatorname{LogL})$; p-value of the likelihood ratio test (LR); Final Prediction Error (FPE); Akaike Information Criteria (AIC); Schwarz Bayesian Information Criteria (BIC); and the Hannan\& Quinn (HQC) Information Criteria 
Table 10 - Johansen co-integration test for cellulose - subperiod 01

\begin{tabular}{lcccc}
\hline & \multicolumn{2}{c}{} & \multicolumn{2}{c}{ Maximum Statistic } \\
& ----Estatistic Trace---- & -------Eigenvalue------- \\
\hline & Calculado & P-valor & Calculado & P-valor \\
\hline $\mathrm{R}=0$ & $46.22673^{* *}$ & 0.0110 & $29.21258^{* * *}$ & 0.0095 \\
\hline $\mathrm{R} \leq 1$ & 17.01415 & 0.3104 & 9.673272 & 0.5202 \\
$\mathrm{R} \leq 2$ & 7.340874 & 0.2925 & 6.357559 & 0.3108 \\
$\mathrm{R} \leq 3$ & 0.983315 & 0.3728 & 0.983315 & 0.3728 \\
\hline
\end{tabular}

Note: ${ }^{* *}$ significant at $5 \%$ and ${ }^{* * *}$ significant at $1 \%$.

In Equation (14), the co-integration vector (normalized) is shown, indicating the long-term relationship between the variables and the respective elasticities.

$$
L B R A_{-} C 01_{t}=-0,51 L B R A_{-} C P 01_{t}+1,92 \text { LINT_C01 } 1_{t}
$$

According to Equation (14), it was verified that the pass-through coefficient was null, indicating that the exchange rate variation did not influence the export price of cellulose in sub-period 02. Studies by COPETTI et al., (2013) for soybeans also reported null pass-through coefficients, corroborating the results of this research. A possible explanation for the null coefficient in sub-period 01 is that exporters chose not to change their price in foreign currency, due to the exchange rate instability that characterized the sub-period. For FERREIRA et al. (1999), the pass-through coefficient is a function, among other factors, of the exchange rate volatility that exporters, in order to preserve their participation in international trade, and realize the exchange rate instability, choose to maintain their prices in foreign currency invariant to exchange rate changes. For this reason, increases in exchange rate variability may be accompanied by a reduction in the pass-through coefficient.

Equation (14), showed that the increase of $1 \%$ in the cost of Brazilian production causes a reduction of $0.51 \%$ in the export price of cellulose in sub-period 01. Although, this result goes from against economic theory, Correa's study (2012) reportedresults of the same magnitude, since an increase of $1 \%$ in the cost of Brazilian production determined a reduction of $0.403 \%$ in the export price of the paper and printing sector.

Based on Equation (14), the increase of $1 \%$ in the international price of cellulose determined an increase of $1.92 \%$ in the export price of cellulose.
Table 11 - VectorCo-integration estimate (normalized) for cellulose - sub-period 01.

\begin{tabular}{lccc}
\hline $\begin{array}{l}\text { LBRA_C01 } \\
(-1)\end{array}$ & $\begin{array}{c}\text { LBRA_CP01 } \\
(-1)\end{array}$ & $\begin{array}{c}\text { LTX_D01 } \\
(-1)\end{array}$ & $\begin{array}{c}\text { LINT_C01 } \\
(-1)\end{array}$ \\
\hline 1,0000 & $0.506607^{* * *}$ & $0.134823 \mathrm{~ns}$ & $1.917454^{* * *}$ \\
& $(0.10108)$ & $(0.11877)$ & $(0.11434)$ \\
& {$[5.01190]$} & {$[1.13513]$} & {$[-16.7698]$} \\
\hline
\end{tabular}

Note 1: LBRA_C01 = Neperian logarithm of Cellulose export price - sub-period 01 (US \$ / ton); LBRA_CP01 = Neperian logarithm of the production cost - sub-period 01; LTX D01 = Neperian logarithm of the exchange rate - sub-period 01 ( $\mathrm{R} \$ /$ US \$); LINT C01 = Neperian logarithm of the international cellulose price - sub-period 01 (North American import price index for cellulose, recovered paper and paper products). Note 2: the values in parentheses refer to the standard error, and those in brackets, to the $\mathrm{t}$ statistic. Note $3:{ }^{* * *}$ significant at $1 \%$; ${ }^{* *}$ significant at $5 \%$, ns not significant.

In order to diagnose the model, serial correction tests were estimated for the residues, results which are shown in table 12.

Analyzing the data presented in table 12, up to twelve defaults, the test indicated the rejection of the null hypothesis that the serial correlation is different from zero, with $1 \%$ significance. Thus, the diagnostic results of the estimated model are valid and present a correct and reliable relationship between the variables in question.

Analysis of sub-period 02 - from Mar / 2008 to Mar / 2018

To perform the co-integration test, it is necessary to check the number of lags to insert from the model (Table 13).Based on the data in table 13, it was possible to indicate that the number of lags is 2 (two) to be included in the VAR, since, of the five criteria considered, all indicated the same number of lags in the auxiliary VAR.

The Johansen co-integration test revealed that in the null hypothesis there is no co-integration vector and that should be rejected at the $1 \%$ level (according to the data in Table 14). In addition, the model of the co-integration equation that best fitted the test was model 3 of the test summary, with the variables at level with linear trend and the cointegration equations with intercepts.

According to table 15, which presents the co-integration vector (normalized), all the estimated coefficients were significant at the level of $5 \%$. In equation (15), the co-integration vector (normalized) 
Table 12 - Serial correlation test for waste from the VEC model for cellulose - sub-period 01.

\begin{tabular}{|c|c|c|c|c|c|c|}
\hline Discrepancy & Est. Q & $\mathrm{p}$-value & Est Ajust.Q & p-value & Est. LM & p-value \\
\hline 1 & 0.857535 & --- & 0.866376 & --- & 21.05283 & 0.1765 \\
\hline 2 & 8.652443 & --- & 8.823678 & --- & 20.34778 & 0.2050 \\
\hline 3 & 24.34233 & 0.6633 & 25.00903 & 0.6273 & 20.00872 & 0.2198 \\
\hline 4 & 42.12919 & 0.5521 & 43.55278 & 0.4907 & 21.80311 & 0.1497 \\
\hline 5 & 62.07908 & 0.4019 & 64.57525 & 0.3199 & 23.28943 & 0.1062 \\
\hline 6 & 76.40506 & 0.4654 & 79.83553 & 0.3595 & 15.70927 & 0.4734 \\
\hline 7 & 87.05468 & 0.6262 & 91.30435 & 0.5009 & 13.68214 & 0.6224 \\
\hline 8 & 107.1307 & 0.5055 & 113.1649 & 0.3478 & 22.28994 & 0.1341 \\
\hline 9 & 118.0256 & 0.6342 & 125.1616 & 0.4539 & 10.91655 & 0.8146 \\
\hline 10 & 128.1055 & 0.7555 & 136.3868 & 0.5706 & 11.94959 & 0.7474 \\
\hline 11 & 139.1713 & 0.8293 & 148.8518 & 0.6455 & 12.19033 & 0.7308 \\
\hline 12 & 150.0828 & 0.8849 & 161.2858 & 0.7102 & 11.48254 & 0.7788 \\
\hline
\end{tabular}

is shown, indicating the long-term relationship between the variables and the respective elasticities.

$$
\begin{aligned}
& \text { LBRA_C02 }=+0,34 \text { LBRA_CP02 }_{\mathrm{t}}=0,36 \text { LTX } \\
& \text { D02 }+1,42 \text { LINT_C02 }+2,36
\end{aligned}
$$

According to Equation (15), it was verified that the pass-through coefficient was incomplete, indicating that the exchange rate variation (R \$ / US \$) partially influenced the Brazilian cellulose export price, that is, the $+1 \%$ variation in the exchange rate causes $-0.36 \%$ variation in the export price of cellulose in sub-period 02 . The study by TEJADA et al. (2008) also reported an incomplete pass-through coefficient for the cellulose sector, paper and printing, as well as the study by CORREA (2012) for the paper and printing sector. Other revised studies on the transfer of exchange rate variations to Brazilian export prices also corroborated the result of an incomplete passthrough (FERREIRA et al., 1999; CRUZ JR. et al., 2004, FRAGA et al, 2008, COPETTI et al., 2012; SOUZA et al., 2018).

Regarding the price strategy adopted by exporters, in the comparison of sub-period 02 in relation to sub-period 01, exporters possibly adopted a PCP position rather than LCP, that is, it was possible to define prices more in reais than in dollars, indicating greater price competitiveness in sub-period 02. Besides, the greater pass-through of sub-period $02(0.36)$ resulted in an increase in the

\begin{tabular}{|c|c|c|c|c|c|c|}
\hline Discrepancy & $\log L$ & LR & FPE & AIC & BIC & HQ \\
\hline 1 & 1440.226 & NA & $5.87 \mathrm{e}-15$ & -21.41693 & -21.06922 & -21.27563 \\
\hline 2 & 1485.728 & $85.53054^{*}$ & $3.77 \mathrm{e}-15^{*}$ & $-21.86057^{*}$ & $-21.16515^{*}$ & $-21.57798^{*}$ \\
\hline 3 & 1497.774 & 21.91851 & $4.01 \mathrm{e}-15$ & -21.80112 & -20.75798 & -21.37723 \\
\hline 4 & 1511.435 & 24.03470 & $4.16 \mathrm{e}-15$ & -21.76594 & -20.37510 & -21.20075 \\
\hline
\end{tabular}

Table 13 - Discrepancy criteria for auxiliary VAR for cellulose - sub-period 02.

Note 1: likelihood value ( $\operatorname{LogL})$; p-value of the likelihood ratio test (LR); Final Prediction Error (FPE); Akaike Information Criteria (AIC); Schwarz Bayesian Information Criterion (BIC); and the Hannan\& Quinn (HQC) Information Criteria.

Note $2:{ }^{*}$ indicates the optimal lag (n) defined by the criteria. 
Table 14 - Johansen cointegration test for cellulose - subperiod 02 .

\begin{tabular}{lcccc}
\hline & \multicolumn{2}{c}{ Estatistic Trace } & \multicolumn{2}{c}{$\begin{array}{c}\text { Maximum Statistic } \\
\text { Eigenvalue }\end{array}$} \\
& Calculado & $\begin{array}{c}\mathrm{P}- \\
\text { valor }\end{array}$ & Calculado & $\begin{array}{c}\mathrm{P} \text { - } \\
\text { valor }\end{array}$ \\
$\mathrm{R}=0$ & $56.08454^{* * *}$ & 0.0070 & $33.06072^{* * *}$ & 0.0089 \\
$\mathrm{R} \leq 1$ & 23.02381 & 0.2449 & 13.70284 & 0.3899 \\
$\mathrm{R} \leq 2$ & 9.320970 & 0.3365 & 8.403149 & 0.3392 \\
$\mathrm{R} \leq 3$ & 0.917820 & 0.3380 & 0.917820 & 0.3380 \\
\hline
\end{tabular}

Note: ${ }^{* *}$ significant at $5 \%$ and ${ }^{* * *}$ significant at $1 \%$.

volume of exports and an increase in the market share of Brazilian cellulose exports, which, from 2000 to 2018 , went from 4th place in the ranking of the world's largest pulp exporters with $7.03 \%$ of the total quantity exported tofirstplace with $23.74 \%$ of the total world share (ITC, 2019).

According to MDIC (2019) and ITC (2019), the average of Brazilian export prices and the international price of cellulose was, in subperiod 01 , respectively, US $\$ 4.02 / \mathrm{kg}$ and US $\$$ $3.70 \mathrm{~kg}$, the Brazilian export price being $8 \%$ above the international price. Conversely, the average of Brazilian export prices and the international price of cellulose, was, in sub-period 02 , respectively, US \$5.01/ kg and US \$ $4.40 \mathrm{~kg}$, with the Brazilian export price $14 \%$ above the international price, a fact possibly attributed to the competitive gain of the highest pass-through coefficient in sub-period 02.

Equation (15), show that the variation of + $1 \%$ in the cost of Brazilian production causes a variation of $+0.34 \%$ in the export price of cellulose in sub-period 02.. It is also possible to infer, based on Equation (15), that the $+1 \%$ variation in the international pulp price determines a $+1.42 \%$ variation in the Brazilian pulp export price in sub-period 02 .

In order to diagnose the model, serial correction tests were estimated for the residues, results which are shown in table 16 . Based on the analysis of the data presented in table 16, up to twelve defaults, the test indicated the rejection of the null hypothesis that the serial correlation is different from zero, with a $5 \%$ significance level. Thus, the diagnostic results of the estimated model are valid and present a correct and reliable relationship between the variables in question.

\section{CONCLUSION}

This research carried out an investigation of the influence of the exchange rate variation on cellulose export prices in the total period and in two sub-periods. In this regard, results indicated that the degree of exchange rate pass-through for cellulose export prices was incomplete. Sub-period 01, conversely, presented a null pass-through coefficient.

From this, it can be inferred that the pass-through coefficients determined that exchange rate depreciations do not translate into significant competitiveness gains, since they did not significantly reduce export prices.

In this way, as exchange rate variations determined reduced effects on the competitiveness of cellulose, being necessary focus on aspects such as the degree of competition in the pricing of this market (pricing to market) and the price elasticity of demand. Therefore, the characteristics of the cellulose market, such as the high concentration, with reduced market

Table 15 - Estimation of the co-integration vector (normalized) for cellulose - sub-period 02.

\begin{tabular}{lcccc}
\hline LBRA_C02 (-1) & LBRA_CP02 (-1) & LTX_D02 (-1) & LINT_C02 (-1) & C \\
\hline 1,0000 & $-0.339642^{* *}$ & $0.363932^{* * *}$ & $-1.422822^{* * *}$ & 2.357716 \\
& $(0.14255)$ & $(0.08693)$ & $(0.42822)$ & - \\
\hline & {$[-2.38264]$} & {$[4.18653]$} & {$[-3.32261]$} & - \\
\hline
\end{tabular}

Note 1: LBRA_C02 = Neperian logarithm of cellulose export price - sub-period 02 (US \$ / ton); LBRA_CP02 = Neperian logarithm of the production cost - sub-period 02; LTX_D02 = Neperian exchange rate logarithm - sub-period 02 (R \$ / US \$); LINT_C02 = Neperian logarithm of the international cellulose price - sub-period 02 (North American import price index for cellulose, recovered paper and paper products). Note 2: the values in parentheses refer to the standard error, and those in brackets, to the t statistic. Note $3:{ }^{* * *}$ significant at $1 \%$; s* significant at $5 \%$, ns not significant. 
Table 16 - Serial correlation test for waste from the VEC model for cellulose - sub-period 02.

\begin{tabular}{|c|c|c|c|c|c|c|}
\hline Discrepancy & Est. Q & p-value & Est Ajust.Q & p-value & Est. LM & p-value \\
\hline 1 & 1.477629 & --- & 1.488823 & --- & 17.45640 & 0.3567 \\
\hline 2 & 4.978010 & --- & 5.042645 & --- & 19.29303 & 0.2538 \\
\hline 3 & 24.38310 & 0.6612 & 24.89554 & 0.6335 & 24.28601 & 0.0834 \\
\hline 4 & 37.65290 & 0.7390 & 38.57681 & 0.7026 & 14.76608 & 0.5418 \\
\hline 5 & 49.84097 & 0.8222 & 51.24097 & 0.7825 & 15.26068 & 0.5056 \\
\hline 6 & 61.95251 & 0.8776 & 63.92472 & 0.8369 & 13.05890 & 0.6684 \\
\hline 7 & 76.40498 & 0.8794 & 79.18010 & 0.8272 & 16.80880 & 0.3981 \\
\hline 8 & 96.58624 & 0.7764 & 100.6530 & 0.6794 & 21.72723 & 0.1522 \\
\hline 9 & 117.3514 & 0.6508 & 122.9253 & 0.5104 & 25.93288 & 0.0550 \\
\hline 10 & 136.4611 & 0.5688 & 143.5886 & 0.4004 & 22.36677 & 0.1317 \\
\hline 11 & 148.8925 & 0.6446 & 157.1409 & 0.4593 & 13.93812 & 0.6033 \\
\hline 12 & 166.4350 & 0.6054 & 176.4231 & 0.3927 & 20.81148 & 0.1859 \\
\hline
\end{tabular}

power of exporters and growth in world income, possibly minimized the price adjustment sue to exchange rate depreciations.

Among the limitations of the present research is the fact that the estimated pass-through coefficient is static, that is, it allowed the general analysis of specific periods of time, not understanding the dynamism of the exchange rate and its period-toperiod influence on the domestic and export prices. In this sense, it is recommended, for further studies, the application of the Kalman filter as a way of capturing the dynamics of the exchange rate pass-through.

\section{ACKNOWLEDGEMENTS}

Was financed in part by the Coordenação de Aperfeiçoamento de Pessoal de Nível Superior (CAPES), Brasil - Finance code 001." This work was supported by Conselho Nacional de Desenvolvimento Científico e Tecnológico (CNPq), through the Edital Universal-2018- Process- 430292/2018-0 and Fundação de Amparo à Pesquisa do Estado do Rio Grande do Sul (FAPERGS)- Process- 17/2551-0001166-0 -EDITAL 02/2017.

\section{DECLARATION OF CONFLICT OF INTERESTS}

The authors declare no conflict of interest. The founding sponsors had no role in the design of the study; in the collection, analyses, or interpretation of data; in the writing of the manuscript, and in the decision to publish the results.

\section{AUTHORS' CONTRIBUTIONS}

The authors contributed equally to the manuscript.

\section{REFERENCES}

BOX, G. E. P. et al. Distribution of residual autocorrelations in autoregressive integrated moving average time series models. Journal of the American Statistical Association, v.65, n.332, p.1509-1526, 1970. Available from: <https://www.jstor.org/ stable/2284333>. Accessed: Jul. 10, 2019. doi: 10.2307/2284333.

BREUSCH, T. S. Testing for autocorrelation in dynamic linear models. Australian Economic Papers, 17, 1978. Available from: $<$ https://onlinelibrary.wiley.com/doi/10.1111/j.1467-8454.1978 tb00635.x>. Accessed: Jul. 09, 2019. doi: 10.1111/j.14678454.1978.tb00635.x.

COPETTI, L. S. et al. Transmissão das variações da taxa de câmbio para os preços de exportação da soja no Brasil e na Argentina. Custos e Agronegócios Online, Recife, v.8, n.3, p.113-132, jul./ set. 2012. Available from: $<\mathrm{http}: / /$ www.custoseagronegocioonline. com.br/numero3v8/cambio.pdf $>$. Accessed: Jun. 08, 2019.

COPETTI, L. S. et al. Transmissão da variação da taxa de câmbio para os preços de exportação da soja em grão: análise dos mercados dos Estados Unidos, do Brasil e da Argentina. Revista em Agronegócios e Meio Ambiente, v.6, n.3, p.435461, set./dez. 2013. Available from: <https://periodicos. unicesumar.edu.br/index.php/rama/article/view/2805>. Accessed: Jun. 06, 2019.

CORREA, A. L. Taxa de câmbio e preços de exportação no Brasil: avaliação empírica dos coeficientes de pass-through setoriais. Economia e Sociedade, Campinas, v.21, n.1 (44), p.61-91, abr. 2012. Available from: <https://periodicos. sbu.unicamp.br/ojs/index.php/ecos/article/view/8642294>. Accessed: Jun. 05, 2019.

COSTA, T. R. et al. Dinâmica competitiva das exportações brasileiras de papel e celulose: uma aplicação da matriz de competitividade. Ciência da Madeira (Brazilian Journal of Wood Science), v.6, n.3, p. 191-201, 2015. Available from:

Ciência Rural, v.50, n.8, 2020. 
$<$ https://periodicos.ufpel.edu.br/ojs2/index.php/cienciadamadeira/ article/view/7141>. Accessed: Jun. 05, 2019. doi: 10.15210/cmad. v6i3.7141.

CRUZ JR. et al. Pass-through da taxa de câmbio nos preços de exportação dos produtos agropecuários brasileiros: 1994-2003. In: Anais do XLII Congresso brasileiro de economia e sociologia rural (SOBER), 2004, Cuiabá-MT, 2004..].

DICKEY, D. A. et al.. Distribution of the estimators for autoregressive time series with a unit root. Journal of the American Statistical Association, v.74, n.366, p.427-431, 1979. Available from: <https://www.jstor.org/stable/2286348>. Accessed: Jun. 04, 2019. doi: 10.2307/2286348

DICKEY, D. A. et al.. A Likelihood ratio statistics for autoregressive time series with a unit root. The Econometric Society, v.49, p.1057-1073, 1981. Available from: <https://www.jstor.org/ stable/1912517>. Accessed: Jun. 04, 2019. doi: 10.2307/1912517.

ENDERS, W. Applied EconometricTime Series. Nova York: John Wiley \& Sons, 1995.

ENGLE, R. F. et. al. Co-integration and error-correction: representation, estimation and testing. Econometrica, Chicago, v.55, n.2, p. 251-276, 1987. Available from: < $<$ https://www.jstor.org/ stable/1913236>. Accessed: Jun. 04, 2019. doi: 10.2307/1913236.

FERREIRA, A. et. al.. Exchange rate pass-through: the case of Brazilian exports of manufactures. In: World Congress Of The International Economic Association, 2, Buenos Aires, ago. 1999.

FRAGA, G. J. et al. O pass-through das variações da taxa de câmbio para os preços de exportação de soja. Revista Análise Econômica, Porto Alegre, n.49, p.193-210, 2008. Available from: <https://seer. ufrgs.br/AnaliseEconomica/article/view/10911>. Accessed: Jun. 04, 2019. doi: 10.22456/2176-5456.10911.

FRED - Federal Reserve Bank of St. Louis. Import Price Index: Woodpulp, recovered paper, and paper products. Available from: <https://fred.stlouisfed.org>. Accessed: Jun. 04, 2019.

GODFREY, L. G. Testing for higher order serial correlation in regression equations when the regressors include lagged dependent variables. Econometrica, 1978. Available from: $<\mathrm{https}: / /$ www.jstor.org/stable/1913830>. Accessed: Jun. 04, 2019. doi: $10.2307 / 1913830$.

GREENE, W. H. Econometrics Analysis. 6.ed. New Jersey: Pearson Education, 2008.

HAMILTON, J. D. Time series analysis. New Jersey: Princeton University Press, 1994.

HARRIS, R.I.D. Using cointegration analysis in econometric modelling. London: Prentice-Hall-Harvester Wheatsheaf,1995.
ITC - International Trade Centre.Trade Map. Available from: $<$ https://www.trademap.org>. Accessed: Jun. 04, 2019.

IPEA - Instituto de Pesquisa Econômica Aplicada. Available from: <http://www.ipeadata.gov.br>. Accessed: Jun. 06, 2019.

JOHANSEN, S. Statistical analysis of cointegration vectors. Journal of Economic Dynamic and Control, v.12, p.231-254, 1988. Available from: <https://www.sciencedirect.com/science/ article/pii/0165188988900413>. Accessed: Jun. 06, 2019. doi: 10.1016/0165-1889(88)90041-3.

KWIAKOWSKI, D. et al. Testing the alternative of stationary against the alternative of a unit root: how sure are we that economic time series have a unit root?Journal of Econometrics. v.54. issues 1-3. p. 159-178, 1992. Available from: <https://www.sciencedirect. com/science/article/abs/pii/030440769290104Y>. Accessed: Jun. 06, 2019. doi: 10.1016/0304-4076(92)90104-Y.

MDIC - Ministério de Desenvolvimento, Indústria e Comércio Exterior. Balança Comercial. Available from: $<\mathrm{http} / / / \mathrm{www}$.mdic. gov.br/index.php/balanca-comercial $>$. Accessed: Jun. 06, 2019.

MENON, J. Exchange rate and import prices for a small open economy. Applied Economics, v.27,n.3,p.297-301,1995. Available from: <https:// www.tandfonline.com/doi/abs/10.1080/00036849500000113>. Accessed: Jun. 06, 2019. doi: 10.1080/00036849500000113.

MUNDLACK, Y. et al.On the transmission of world agricultural prices. The World Bank Review, v.6, n.1, p.399-422, 1992. Available from: $<$ http://documents.worldbank.org/curated/en/299801468765016715/Onthe-transmission-of-world-agricultural-prices $>$. Accessed: Jun. 03, 2019.

OBSTFELD, M. et al. Exchange rate dynamics redux. Journal of Political Economy, v. 103 (3), p. 624-660, 1995. Available from: <http://nrs.harvard.edu/urn-3:HUL.InstRepos:12491026>. Accessed: May, 27, 2019. doi: 10.3386/w4693.

OLAVO, R. F. et al. Estudo da competitividade internacional do complexo agroindustrial brasileiro de papel e celulose, 19902013. In: Anais do XII Encontro da Associação Brasileira de Estudos Regionais e Urbanos (ENABER), 2015, Curitiba-PR, 2015.

SOUZA, D. K. F. et. al. Análise do pass-through da taxa de câmbio para os preços de exportação do açúcar. In: Anais do $56^{\circ}$ Congresso da Sociedade Brasileira de Economia, Administração e Sociologia Rural - SOBER, Campinas - SP, 2018.

TEJADA, C. A. O. et. al. O pass-through das variações da taxa de câmbio para os preços dos principais produtos exportados pelo Brasil. Revista de Economia e Sociologia Rural, v.46, n.01, p.171-205, jan-mar/2008. Available from: $<$ https://www.scielo.br/ scielo.php?script $=$ sci_arttext\&pid $=\mathrm{S} 0103-20032008000100008>$. Accessed:Mai.28,2019. doi: 10.1590/S0103-20032008000100008.

WTO - World Trade Organization. Tariff Analysis Online. Available from: <http://tao.wto.org/>. Accessed: Jun. 05, 2019. 